\title{
Species-specific polymerase chain reaction primer sets for the diagnosis of Tenacibaculum maritimum infection
}

\author{
Rubén Avendaño-Herrera, Beatriz Magariños, Alicia E. Toranzo, \\ Roxana Beaz, Jesús L. Romalde*
}

Departamento de Microbiología y Parasitología, Facultad de Biología, Universidad de Santiago, 15782 Santiago de Compostela, Spain

\begin{abstract}
In this study the specificity and sensitivity of 2 primer pairs, MAR1-MAR2 and Mar1Mar2, for the detection of Tenacibaculum maritimum were evaluated in parallel using $79 \mathrm{~T}$. maritimum strains isolated from different fish species, as well as 53 representatives of related and unrelated bacterial species. Both primer pairs were species-specific for T. maritimum, since no amplification products were obtained from chromosomal DNA of the non-T. maritimum bacteria tested. However, whereas MAR1-MAR2 identified all the T. maritimum strains studied, producing a unique and clear PCR band of the expected $1088 \mathrm{bp}$ length, the Mar1-Mar2 primer pair failed to amplify the $400 \mathrm{bp}$ specific band in 3 sole isolates. To verify if these strains belonged to T. maritimum species, 2 endonucleases ( $P$ vuI and $S a c I I)$ were selected as the most adequate enzymes to confirm the specificity of the MAR1-MAR2 amplified fragment. The digestion patterns obtained with both endonucleases supported the assignation of all the strains to T. maritimum. The sensitivity of both PCR detection methods was also different, showing a reduction of sensitivity in at least one order of magnitude of the Mar1-Mar2 primer pair in comparison with MAR1-MAR2. When the MAR-MAR2 PCR protocol was applied to different seeded turbot tissues, the detection limit was $10^{2}$ to $10^{4} \mathrm{~T}$. maritimum cells per reaction. In addition, a nested PCR protocol for detection of this pathogens based on MAR1-MAR2 was developed, which increased the sensitivity by approximately 2 orders of magnitude, ranging from 1 to $250 \mathrm{~T}$. maritimum cells per reaction depending on the tissue employed. The tissues that allowed the most easy detection of T. maritimum were the skin and mucus. Based on the findings reported here, we propose the nested PCR protocol as the most adequate for an accurate detection of T. maritimum in diagnostic pathology as well as in epidemiological studies of gliding bacterial disease of marine fish.
\end{abstract}

KEY WORDS: Tenacibaculosis $\cdot$ Tenacibaculum maritimum $\cdot$ Nested-PCR $\cdot$ Diagnosis

\section{INTRODUCTION}

Diseases caused by bacteria are recognized as major problems affecting the marine fish farming through the world (Austin \& Austin 1999, Osorio \& Toranzo 2002). Although pathogenic species have been described in most of the existent taxonomic groups, only a small number are responsible for important economic losses in extensive culture worldwide. Tenacibaculum maritimum (formerly Flexibacter maritimus) (Suzuki et al. 2001) has been included among these microorganisms, being the causative agent of gliding bacterial disease (or tenacibaculosis) in a great variety of valuable marine fish species such as turbot Scophthalmus maximus, salmon Salmo salar and Oncorhynchus kisutch, sole Solea senegalensis and Solea solea, gilthead seabream Sparus aurata, red and black seabream Pagrus major and Acanthopagrus schlegeli, and floun- 
der Paralichthys olivaceus (McVicar \& White 1979, Wakabayashi et al. 1984, Devesa et al. 1989, Bernardet et al. 1990, Pazos et al. 1993, Chen et al. 1995, Ostland et al. 1999, Santos et al. 1999, Bader \& Starliper 2002, Avendaño-Herrera et al. 2004a).

The disease is preliminarily diagnosed by the clinical signs of the affected fish which usually show eroded and hemorrhagic mouths, ulcerative skin lesions, frayed fins and tail rot. This diagnosis must be supported by the isolation of colonies of this pathogen on appropriate specific media (Pazos et al. 1996), followed by biochemical identification. This traditional culture-based method for the detection of the pathogen requires several days to weeks before results are obtained. In addition, one of the problems in the study of Tenacibaculum maritimum is the difficulty of distinguishing it from other phenotypically similar and phylogenetically related species, particularly those of the genera Flavobacterium and Cytophaga (Suzuki et al. 2001, Bader \& Starliper 2002). Another disadvantage in the diagnosis of this infection is the problem of recognizing the colonies of T. maritimum among the mixed population that usually overgrow the $T$. maritimum colonies, due to the slow growth characteristic of T. maritimum.

All these features make DNA-based methods a very worthwhile approach for diagnosis of tenacibaculosis. Polymerase chain reaction (PCR) has been established as an alternative to traditional detection methods in microbial diagnostics due to the fact that this technique provides a powerful tool for accurate identification of the pathogen from plate cultures, as well as from fish tissues (Cunningham 2002, Osorio \& Toranzo 2002). Two PCR primer pairs have been designed for the detection of Tenacibaculum maritimum using the 16S ribosomal RNA (rRNA) gene as target. Toyama et al. (1996) selected a pair of primers (MAR1 and MAR2; positions 190 to 206 and 1262 to 1278 respectively in the Escherichia coli 16S rRNA numbering system), flanking a 1088 base pair (bp) fragment, which could differentiate $T$. maritimum from the related species Flavobacterium branchiophilum and F. columnare, as well as from several other fish pathogenic bacteria. More recently, Bader \& Shotts (1998) also selected a pair of T. maritimum species-specific PCR primers (Mar1 and Mar2; positions 77 to 98 and 456 to 476 respectively) from unique sequence stretches within this gene, delimiting a $400 \mathrm{bp}$ DNA fragment.

However, despite the potential of PCR detection, these primers sets have not been tested simultaneously in order to compare their efficiency using a wide range of strains isolated from different species of marine fish and the environment. In the same way, neither Toyama et al. (1996) or Bader \& Shotts (1998) determined the actual detection limits of each primer set with pure and mixed cultures, as well as in fish samples. Therefore, the aim of this study was to examine the specificity and sensitivity of the 2 PCR methods described previously for the identification of the Tenacibaculum maritimum strains. In addition, primers described by Toyama et al. (1996) were used to develop a nested PCR method for specific diagnosis of marine tenacibaculosis in fish samples.

\section{MATERIALS AND METHODS}

Bacterial strains and growth conditions. The bacterial strains used in the primer specificity studies are listed in Tables $1 \& 2$. This collection comprises 76 Tenacibaculum maritimum strains isolated from 7 different fish species from 1995 to 2003 (Table 1) and 3 reference strains (NCIMB 2153, 2154 ${ }^{\mathrm{T}}$ and 2158) from the National Collection of Industrial and Marine Bacteria (Aberdeen, UK) (Table 1). These belong to the main serotypes and clonal lineages described within this pathogen (Avendaño-Herrera et al. 2004a,b). For all experiments, these strains were routinely cultured on Flexibacter maritimus Medium (FMM) agar (Pazos et al. 1996) and incubated at $20^{\circ} \mathrm{C}$ for $72 \mathrm{~h}$. Before the assay, all bacterial strains were confirmed as T. maritimum using biochemical tests and serological assays according to Avendaño-Herrera et al. (2004a). In addition, 5 reference strains of other species of the genus Tenacibaculum; T. ovolyticum, T. mesophilum and T. amylolyticum (NBRC 15947, 15992, 16307 ${ }^{\mathrm{T}}, 16308$ and $16310^{\mathrm{T}}$ ), obtained from the NITE (National Institute of Technology and Evaluation) Biological Resource Center (Osaka, Japan), 27 strains of related filamentous bacterial species obtained from fish and seaweed and 21 pathogenic fish bacteria were also included as negative controls in the PCR (Table 2). Stock cultures were stored at $-70^{\circ} \mathrm{C}$ in Cryo-bille tubes (AES Laboratory).

DNA extraction from pure and mixed bacterial culture. Chromosomal DNA was extracted using InstaGene Matrix (Bio-Rad) for pure bacterial cultures as previously described by Romalde et al. (1999). Briefly, Tenacibaculum maritimum and other non-T. maritimum bacterial species colonies were collected from the appropriate agar plates, suspended in $1 \mathrm{ml}$ of sterile distilled water and centrifuged at $12000 \times g$ for $1 \mathrm{~min}$. After the supernatants were removed, the pellets were resuspended in $200 \mu \mathrm{l}$ of InstaGene Matrix and incubated at $56^{\circ} \mathrm{C}$ for $30 \mathrm{~min}$. Then, the suspensions were mixed at high speed for $10 \mathrm{~s}$ and boiled in a water bath for $8 \mathrm{~min}$. The lysates were mixed again at high speed and then were spun at $12000 \times g$ for $3 \mathrm{~min}$. The concentration and quality of each DNA sample was examined spectrophotometrically at $260 \mathrm{~nm}$. DNA from pure 
cultures was adjusted to a concentration of $30 \pm 2 \mathrm{ng}$ $\mathrm{ul}^{-1}$. All DNA was maintained at $-20^{\circ} \mathrm{C}$ until used for PCR reactions. All the experiments were carried out with DNA obtained in 3 different extractions for each bacterial strain.

PCR amplification. All PCR amplifications were performed with the commercial kit Ready-To-Go ${ }^{\mathrm{TM}}$ PCR beads (Amersham Pharmacia Biotech), which included all the reagents needed for the PCR reactions (buffer, nucleotides and Taq DNA polymerase), with the exception of the specific primers and DNA template. Two species-specific primer pairs synthesized by Sigma-Genosys were used for the identification of Tenacibaculum maritimum: primers MAR1 (5'-AATGGCATCGTTTTAAA-3') and MAR2 (5'-CGCTCTCTGTTGCCAGA-3') described by Toyama et al. (1996), and primers Mar1 (5'-TGTAGCTTGCTACAGATGA-3') and Mar2 (5'-AAATACCTACTCGTAGGTACG-3') designed by Bader \& Shotts (1998), which give amplification products of 1088 and $400 \mathrm{bp}$ respectively. One $\mu \mathrm{l}$ of each DNA solution and $2 \mu \mathrm{mol}$ of each primer were used in the amplification reaction. All samples were subjected to 40 cycles of amplification in 2 different thermal cyclers. Reaction mixtures $(25 \mu l)$ were simultaneously amplified in $\mathrm{T}$ Gradient Thermocycler (Biometra) and Mastercycler personal (Eppendorf) apparatus. The amplification cycles used for denaturation, primer annealing to the template and primer extension were carried out according to each published PCR protocol. Negative controls, consisting of the same reaction mixture but with sterile distilled water instead of template DNA, were included in each batch of PCR reaction. The reproducibility of the results was assessed by repetition of the amplifications in at least 3 independent PCR assays.

Analysis of PCR products. Amplified products were detected by horizontal $1 \%(\mathrm{w} / \mathrm{v})$ agarose gel electrophoresis for $60 \mathrm{~min}$ at $100 \mathrm{~V}$ in TAE $1 \times(0.04 \mathrm{M}$ Tris, 0.0001 M EDTA, pH 8.0) electrophoresis buffer, visualized using $0.06 \mu \mathrm{g} \mathrm{ml}^{-1}$ of ethidium bromide (Bio-Rad) and photographed under UV light and computer digitised (Gel Doc 100, Bio-Rad). A 50 to 2000 bp ladder (Sigma Chemical) was used as a molecular mass marker. The presence of a single product of the appropriate size, identical to the reference strains, was considered as a positive result.

Restriction enzyme digestion. After the analysis of all PCR products, the isolates identified as Tenacibaculum maritimum with only one of the primer sets were subjected to restriction enzyme digestion. The MapDraw software from the Lasergene Navigator package (DNASTAR) was used to select the most adequate and specific restriction endonucleases for the $1088 \mathrm{bp}$ amplification product. This selection was made on the basis of number, diversity and distribution of restriction fragments produced. Briefly, $2 \mu \mathrm{l}$ of PCR product from each strain amplified by MAR1 and MAR2 was digested with 30 units of the restriction enzyme $P v u I$ or SacII (Amersham Biosciences) according to the instructions of the manufacturer. Ten $\mu \mathrm{l}$ of the digested solution was analysed by horizontal electrophoresis. The restriction fragments of the PCR products from the reference strains were considered as positive controls.

Determination of PCR sensitivity from pure and mixed cultures. The detection limits of both speciesspecific primer sets were evaluated using bacterial suspensions of all reference strains. Pure colonies of Tenacibaculum maritimum were picked from FMM agar plates, adjusted to contain $10^{9}$ cells ml $^{-1}$ (McFarland Scale 4) and serially diluted in $0.85 \%$ sterile saline solution from $10^{8}$ to 10 cells ml ${ }^{-1}$. To determine the usefulness of the primer sets to amplify template DNA of $T$. maritimum from mixed cultures, bacterial suspensions of Listonella anguillarum (R82), Photobacterium damselae subsp. piscicida (TW 398), Aeromonas salmonicida (ATCC 14174) and Lactococcus garvieae (TW94W) were employed. Thus, bacterial mixtures of $T$. maritimum with 2 other different fish pathogens were prepared for PCR sensitivity testing. To each dilution of the T. maritimum strain, $100 \mu \mathrm{l}$ of each bacterial suspension that contained approximately $10^{7}$ cells ml-1 ${ }^{-1}$ was added. Colony forming units (CFU) were estimated by plating each dilution onto appropriate media and counting the bacterial colonies produced.

All the dilutions of pure and mixed cultures were centrifuged at $12000 \times g$ for $2 \mathrm{~min}$ and washed twice with sterile distilled water to extract genomic DNA as before. Conditions for PCR amplification and electrophoresis were the same as described above.

Determination of PCR sensitivity from seeded fish samples. On the basis of the results obtained using bacterial cultures, PCR sensitivity was determined employing DNA extracted from in vitro seeded mucus, skin, kidney and blood, using the Toyama et al. (1996) protocol. All the tissue samples were taken from healthy Tenacibaculum maritimum-free juvenile turbot (12 g body weight). Mucus samples were obtained with a sterile $10 \mu$ plastic loop or with a sterile scalpel blade by cutting the fish on the lateral line (Evans et al. 2001). The samples were then homogenized with $100 \mu \mathrm{l}$ in phosphate buffered saline (PBS, pH 7.4) by repeated pipetting. In the case of skin and kidney, samples were collected using aseptic technique and divided into 500 and $30 \mathrm{mg}$ pieces respectively. One hundred $\mu \mathrm{l}$ of blood samples were collected by vein puncture with a syringe and processed immediately. Each fish sample was seeded with $100 \mu \mathrm{l}$ of the different dilutions of a culture suspension and homogenized 
for $60 \mathrm{~s}$. The 3 reference strains of T. maritimum were tested in parallel. After incubation for $1 \mathrm{~h}$, DNA extraction was performed with Dynabead ${ }^{\circledR}$ DNA DIRECT ${ }^{\mathrm{TM}}$ (Dynal) following the manufacturer's instruction, with the exception of blood samples, from which DNA was extracted as described above for bacterial culture. Non-inoculated fish samples, employed as negative controls, were processed in the same manner but with PBS instead of bacterial dilution. DNA obtained from the different tissues were maintained frozen at $-20^{\circ} \mathrm{C}$ until used for PCR reactions. Conditions for PCR amplification and electrophoresis were the same as described above. In order to determine the reproducibility of results, all traits were assessed by repetition in at least 3 independent PCR assays, in which DNA obtained in 3 different extractions were employed.

Nested PCR amplification. To increase the sensitivity of the Toyama et al. (1996) PCR assay, a nested PCR was conducted on the whole dilution series from pure and mixed cultures, as well as infected tissues and blood with each reference strain. The first round of PCR was performed according to a previously described protocol (Edwards et al. 1989) with minor modifications. We used the same commercial reaction mixture and the universal primer pair pA (5'-AGAGTTTGATCCTGGCTCAG-3') and pH (5'-AAGGAGGTGATCCAGCCGCA-3') but the number of cycles was shortened to 25 . These primers amplify the region from position 20 to position 1521 (Escherichia coli numbering system) of the $16 \mathrm{~S}$ rRNA gene. After the first amplification by external primer was finished, $1 \mu \mathrm{l}$ of each PCR product was used as template for the second amplification by the species-specific primer set MAR1 and MAR2. PCR samples were examined by gel electrophoresis and the samples were considered positive if the anticipated $1088 \mathrm{bp}$ product was observed.

\section{RESULTS}

\section{PCR amplification}

To test the specificity of each primer pair on the identification of Tenacibaculum maritimum, DNA extracted from 79 strains of the target species as well as from 53 strains of other species were used for the PCR with each of the primer pairs. The MAR1-MAR2 primer pair identified all the $T$. maritimum strains studied, producing a unique and clear PCR product of the expected 1088 bp length. In contrast, the Mar1-Mar2 primer pair was capable of amplifying the $400 \mathrm{bp}$ specific band from 76 of 79 strains of T. maritimum analyzed. The 3 T. maritimum strains (AZ202.1, AZ203.1 and PC438.1) not recognized by the Bader \& Shotts (1998) pair of primers were isolated from sole (Table 1). Regardless of the primer set employed, amplification products were not obtained from the other bacterial species tested (Table 2).

When both PCR protocols were compared using 2 different thermal cyclers, no differences were detected in the results of the amplification products. In addition, reproducibility of PCR results was demonstrated since the same results were obtained in at least 3 independent PCR assays for each primer set tested.

\section{Restriction enzyme digestion}

To verify if the 3 isolates from sole only recognized using the Toyama et al. (1996) primer set belonged to Tenacibaculum maritimum species, 2 endonucleases ( $P$ vuI and SacII) were selected as the most adequate to confirm the specificity of the amplified fragment. The

Table 1. Tenacibaculum maritimum strains used in this study and the results from the specific single PCR detection methods employed. NCIMB: National Collection of Marine and Industrial Bacteria (Aberdeen, UK)

\begin{tabular}{|c|c|c|c|c|}
\hline \multirow[t]{2}{*}{ Type of samples } & \multirow[t]{2}{*}{ Isolation source } & \multirow[t]{2}{*}{ No. of strains } & \multicolumn{2}{|c|}{ No. of strains identified with sets } \\
\hline & & & MAR1-MAR2 & Mar 1-Mar2 \\
\hline \multirow{7}{*}{$\begin{array}{l}\text { Strains isolated from diseased } \\
\text { fish (kidney and/or skin) }\end{array}$} & Scophthalmus maximus & 49 & 49 & 49 \\
\hline & Solea senegalensis & 17 & 17 & 14 \\
\hline & Solea solea & 1 & 1 & 1 \\
\hline & Sparus aurata & 5 & 5 & 5 \\
\hline & Salmo salar & 1 & 1 & 1 \\
\hline & Seriola quinqueradiata & 1 & 1 & 1 \\
\hline & Dicentrarchus labrax & 2 & 2 & 2 \\
\hline \multicolumn{5}{|l|}{ Reference strains } \\
\hline T. maritimum NCIMB2153 & Acanthopagrus schlegeli & 1 & 1 & 1 \\
\hline T. maritimum NCIMB $2154^{\mathrm{T}}$ & Pagrus major & 1 & 1 & 1 \\
\hline T. maritimum NCIMB 2158 & Solea solea & 1 & 1 & 1 \\
\hline
\end{tabular}


Table 2. Bacteria from other species included in this study as negative controls in the PCR analysis. NBRC: NITE Biological Resource Center (Osaka, Japan); ATCC: American Type Culture Collection (Rockville, USA); NCIMB: National Collection of Industrial and Marine Bacteria (Aberdeen, UK). No amplification by PCR was detected with either primer set tested. Numbers in parentheses indicate the number of strains assayed

\begin{tabular}{|c|c|}
\hline Bacterial strains & Source \\
\hline Tenacibaculum ovolyticum NBRC 15947 & NBRC \\
\hline Tenacibaculum ovolyticum NBRC 15992 & NBRC \\
\hline Tenacibaculum mesophilum NBRC $16307^{\mathrm{T}}$ & NBRC \\
\hline Tenacibaculum mesophilum NBRC 16308 & NBRC \\
\hline Tenacibaculum amylolyticum NBRC $16310^{\mathrm{T}}$ & NBRC \\
\hline \multicolumn{2}{|l|}{ Flexibacter-like isolated from (17) } \\
\hline diseased fish (kidney and/or skin) & Laboratory collection \\
\hline Flexibacter-like isolated from seaweed (6) & Laboratory collection \\
\hline Flavobacterium sp. (4) & Laboratory collection \\
\hline Flavobacterium psychrophilum PT41 & Laboratory collection \\
\hline Pseudomonas fluorescens ATCC $13525^{\mathrm{T}}$ & ATCC \\
\hline Pseudomonas aeruginosa ATCC 27853 & ATCC \\
\hline Aeromonas salmonicida ATCC 14174 & ATCC \\
\hline Aeromonas media ATCC $33907^{\mathrm{T}}$ & ATCC \\
\hline Alcaligenes pacificus ATCC 27122 & ATCC \\
\hline Vibrio ordalii NCIMB 2107 & NCIMB \\
\hline Streptococcus parauberis RA9 & Laboratory collection \\
\hline Lactococcus garvieae TW94W & Laboratory collection \\
\hline Streptococcus iniae 990 & Laboratory collection \\
\hline Pseudomonas anguilliseptica 899 & Laboratory collection \\
\hline Renibacterium salmoninarum ATCC $33209^{\mathrm{T}}$ & ATCC \\
\hline Yersinia ruckeri TWS30 & Laboratory collection \\
\hline Photobacterium damselae subsp. piscicida TW 398 & Laboratory collection \\
\hline Listonella anguillarum R82 & Laboratory collection \\
\hline Vibrio harveyi TW425 & Laboratory collection \\
\hline Vibrio splendidus I PC400.1 & Laboratory collection \\
\hline Vibrio alginolyticus ATCC $17749^{\mathrm{T}}$ & ATCC \\
\hline Vibrio vulnificus A11 & Laboratory collection \\
\hline Vibrio pelagius I PC376.1 & Laboratory collection \\
\hline Vibrio pelagius II RQ167.1 & Laboratory collection \\
\hline
\end{tabular}

coincident with the expected sizes calculated using the MapDraw software. Thus, endonuclease PvuI rendered 2 fragments of 400 and $688 \mathrm{bp}$, while the enzyme SacII produced 2 bands of 336 and $752 \mathrm{bp}$.

\section{Detection limit for the primer pairs}

The sensitivity and robustness of each species-specific PCR primer set were determined by amplification of DNA extracted from different bacterial suspensions $\left(10^{8}\right.$ to 10 cells $\left.\mathrm{ml}^{-1}\right)$ of 3 Tenacibaculum. maritimum reference strains (Table 3). When the MAR1MAR2 primer pair was tested, the expected $1088 \mathrm{bp}$ PCR product was obtained with samples containing as low as 80 to 500 cells per PCR tube (Fig. 2A). With respect to Mar1-Mar2 primer pair, a fragment of the expected size (400 bp) was also amplified, allowing the detection of $8 \times 10^{2}$ to $5 \times 10^{3} \mathrm{~T}$. maritimum cells per PCR tube (Fig. 2B).

When DNA extracted from mixed cultures were used as template in single PCR amplification, the limits of detection of the Tenacibaculum maritimum with the 2 primer sets were identical to the level of amplification obtained with DNA from pure culture of reference strains (Table 3). Therefore, the other species of fish pathogens assayed did not interfere in the PCR sensitivity, even when high concentrations of non- $T$. maritimum strains were employed $\left(4.0 \pm 1 \times 10^{6}\right.$ CFU ml-1). restriction profiles of the PCR products obtained with the Toyama et al. (1996) primers, including the isolates not recognized as $T$. maritimum by Mar1 and Mar2 were identical for all the strains tested (Fig. 1), and

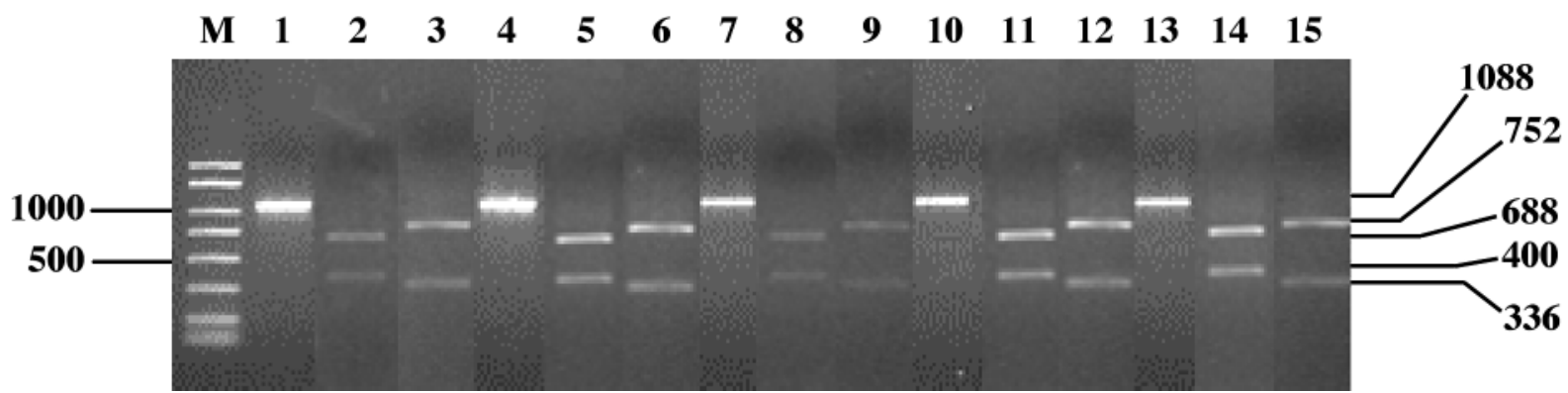

Fig. 1. Specific PCR products obtained with MAR1 and MAR2 (lanes 1, 4, 7, 10, 13) and digestion of the amplified product with the restriction enzymes PvuI (lanes 2, 5, 8, 11, 14) and SacII (lanes 3, 6, 9, 12, 15). Lanes: M: AmpliSize Molecular Ruler (50-2000bp ladder, Sigma); 1-3: Tenacibaculum maritimum reference strain NCIMB 2153; 4-6: Tenacibaculum maritimum

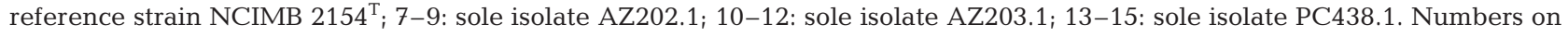
the left indicate the position of molecular size marker in bp. Numbers on the right indicate the size of the specific amplicons and the endonuclease restriction products in $\mathrm{bp}$ 
Table 3. Sensitivity obtained with the different PCR protocols evaluated in single- and nested-PCR using pure and mixed cultures, as well as fish samples seeded with Tenacibaculum maritimum. CFU: colony forming units; NA: no amplification product; NT: not tested

\begin{tabular}{|c|c|c|c|c|c|c|}
\hline \multirow[b]{3}{*}{ Cultures } & \multicolumn{4}{|c|}{ MAR1-MAR2 } & \multicolumn{2}{|c|}{$\begin{array}{l}\text { - Mar1-Mar2 } \\
\text { - Single PCR }\end{array}$} \\
\hline & Cells tube ${ }^{-1}$ & $\begin{array}{c}\text { gle PCR } \\
\qquad \begin{array}{c}\text { CFU ml } \\
\text { or }\end{array} \\
\text { CFU g } \\
\text { C }\end{array}$ & Cells tube ${ }^{-1}$ & $\begin{array}{l}\mathrm{CFU} \mathrm{ml}^{-1} \\
\text { or } \\
\mathrm{CFU} \mathrm{g}^{-1}\end{array}$ & Cells tube ${ }^{-1}$ & $\begin{array}{c}\text { CFU ml } \mathrm{ml}^{-1} \\
\text { or } \\
\mathrm{CFU} \mathrm{g}^{-1}\end{array}$ \\
\hline & & & & & & \\
\hline Pure & $80-500^{\mathrm{a}}$ & $1.6 \times 10^{4}-1.1 \times 10^{5}$ & $1-5$ & $1.6 \times 10^{2}-1.1 \times 10^{3}$ & $8 \times 10^{2}-5 \times 10^{3}$ & $1.6 \times 10^{5}-1.1 \times 10^{6}$ \\
\hline Mixed & $80-500$ & $1.6 \times 10^{4}-1.1 \times 10^{5}$ & $1-5$ & $1.6 \times 10^{2}-1.1 \times 10^{3}$ & $8 \times 10^{2}-5 \times 10^{3}$ & $1.6 \times 10^{5}-1.1 \times 10^{6}$ \\
\hline \multicolumn{7}{|c|}{ Fish samples } \\
\hline Mucus & $1-2 \times 10^{4}$ & $5-6 \times 10^{6}$ & $1-3$ & $5-6 \times 10^{3}$ & NT & NT \\
\hline Skin & $160-250$ & $1-1.5 \times 10^{4}$ & $1-3$ & $1-1.5 \times 10^{2}$ & NT & NT \\
\hline Kidney & NA & NA & $160-250$ & $1.7-2.3 \times 10^{5}$ & NT & NT \\
\hline Blood & $1-3 \times 10^{4}$ & $2-4 \times 10^{6}$ & $5100-200$ & $2-4 \times 10^{4}$ & NT & NT \\
\hline
\end{tabular}

\section{PCR sensitivity from infected fish samples and blood}

With the knowledge that the Toyama et al. (1996) protocol allowed the confirmation of all Tenacibaculum maritimum strains examined and due to the best sensitivity achieved with this protocol in pure and mixed cultures, only the primer pair MAR1-MAR2 was
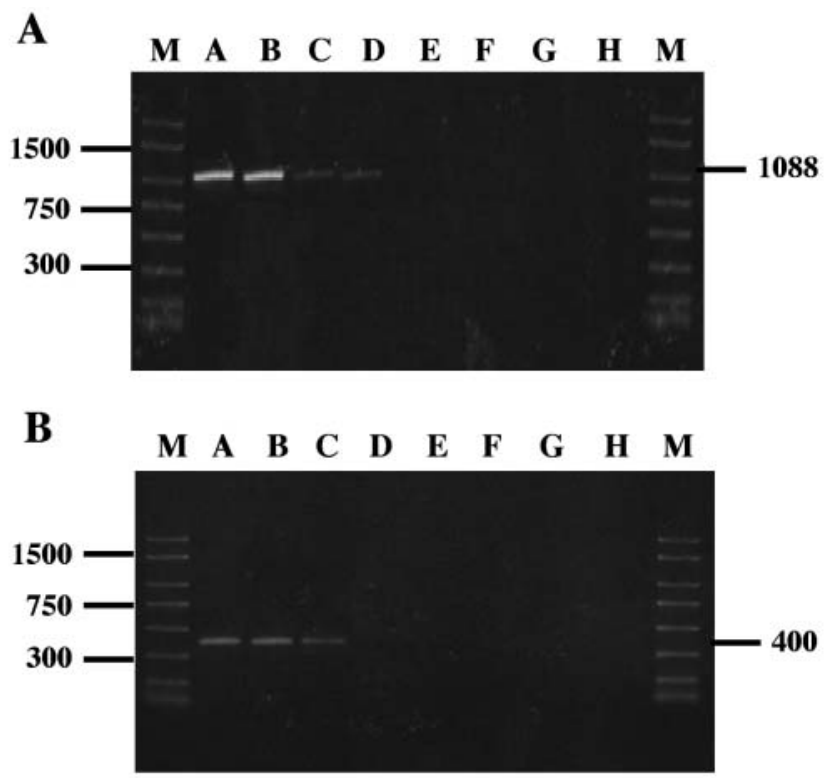

Fig. 2. Sensitivity of PCR protocol using (A) MAR1-MAR2 and (B) Mar1- Mar2 primer sets. Lanes M: AmpliSize Molecular Ruler (50 to 2000 bp ladder, Sigma); Lanes 1 to 8: serial decimal dilutions of the chromosomal DNA extracted from reference strain NCIMB $2154^{\mathrm{T}}$, ranging from $4 \times 10^{8}$ (Lane 1) to $4 \times 10^{1}$ (Lane 8 ) cells $\mathrm{ml}^{-1}$. Numbers on the left indicate the position of molecular size marker in bp. Numbers on the right indicate the size of the specific amplified products in bp tested with DNA extracted from the experimentally seeded fish tissues and blood. Application of the PCR protocol described above showed that $T$. maritimum could be detected in mucus, skin and blood at a detection level on the order of $10^{2}$ to $10^{4}$ cells per reaction. However, no amplification product was observed when DNA samples of kidney were tested (Table 3). When the tissues used as negative controls were tested with the same primers, no amplification occurred. Finally, the total time for the procedure, including DNA extraction from samples, amplification and gel electrophoresis, was shorter than $7 \mathrm{~h}$.

\section{Nested PCR amplification}

When $1 \mu \mathrm{l}$ of the first round product amplified with the universal primer set was used as a template for speciesspecific primer in nested PCR assays, the detection limit of all assays decreased by approximately 2 to 3 orders of magnitude compared with conventional PCR assay, regardless of the type of samples employed (Table 3). Then, when pure and mixed cultured Tenacibaculum maritimum were used in DNA extraction and nested PCR amplification, the detection limit achieved was about 1 to 5 bacteria per PCR tube (which corresponds to $1.6 \times 10^{2}$ to $1.1 \times 10^{3} \mathrm{CFU} \mathrm{ml}^{-1}$ ). In the case of DNA extracted from mucus and skin samples the nested PCR methods allowed the detection of approximately 1 to $3 \mathrm{~T}$. maritimum cell per PCR tube (Fig. 3), and showed a reduction of sensitivity in 1 or 2 log-units for the blood samples. Although the single PCR did not yield amplification products in kidney samples, the nested PCR produced a unique and clear fragment of the expected size (1088 bp) when using this tissue, a sensitivity of approximately $2 \times$ 
$\begin{array}{llllllllllllllllll}M & 1 & 2 & 3 & 4 & 5 & 6 & 7 & M & 8 & 9 & 10 & 11 & 12 & 13 & 14 & 15\end{array}$
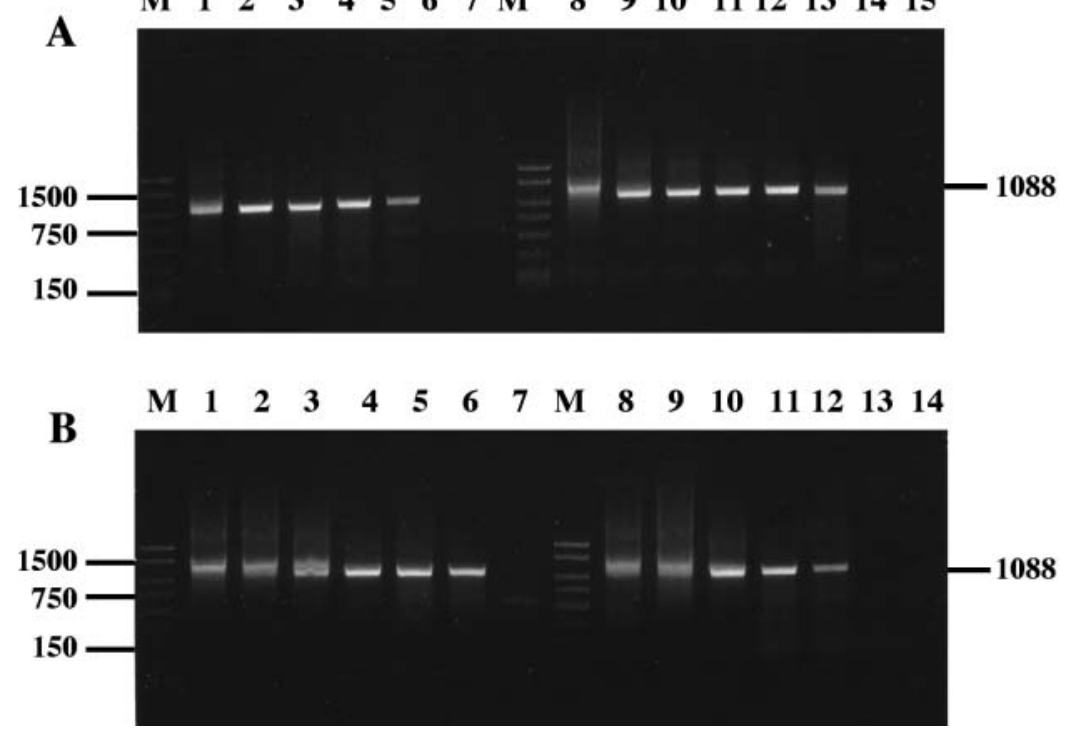

Fig. 3. Detection by nested PCR of Tenacibaculum maritimum in turbot tissues seeded with decimal dilutions of the reference strain NCIMB $2154^{\mathrm{T}}$. Tissues evaluated were (A) blood and mucus and (B) skin and kidney. Lanes in A: M: AmpliSize Molecular Ruler (50 to 2000 bp ladder, Sigma); 1 to 7: DNA extracted from blood seeded with decimal dilutions ranging from $4 \times 10^{8}$ (Lane 1) to $4 \times$ $10^{2}$ (Lane 7) cells $\mathrm{ml}^{-1} ; 8-14$ : DNA extracted from mucus seeded with decimal dilutions ranging from $4 \times 10^{8}$ (Lane 8 ) to $4 \times 10^{2}$ (Lane 15) cells ml ${ }^{-1} ; 15$, negative control (no DNA). Lanes in B: M: AmpliSize Molecular Ruler (50 to $2000 \mathrm{bp}$ ladder, Sigma); 1 to 7: DNA extracted from skin seeded with decimal dilutions ranging from $4 \times 10^{8}$ (Lane 1) to $4 \times 10^{2}$ (Lane 7 ) cells $\mathrm{ml}^{-1}$; 8 to 14: DNA extracted from kidney seeded with decimal dilutions ranging from $4 \times 10^{8}$ (Lane 8) to $4 \times 10^{2}$ (Lane 14) cells $\mathrm{ml}^{-1}$. Numbers on the left indicate the position of molecular size marker in bp. Numbers on the right indicate the size of the specific amplified products in bp

$10^{5} \mathrm{CFU} \mathrm{g}^{-1}$ fish tissue being observed. DNA extracted from fish samples used as negative controls did not yield any amplification product. The total procedure, from the point of DNA extraction to observation in an agarose gel, was increased to $9 \mathrm{~h}$ with the second round of PCR.

\section{DISCUSSION}

One of the most critical steps in the study of bacterial fish diseases is the correct identification of the infectious agent. Rapid diagnosis of outbreaks is essential for an effective control, but current microbiological methods based on culture and biochemical characterization are time-consuming. To overcome these difficulties, DNA-based methods have been developed in recent years for the fast and sensitive diagnosis of the bacterial pathogens in aquatic species. In the case of Tenacibaculum maritimum, Toyama et al. (1996) and Bader \& Shotts (1998) used the 16S rRNA gene sequence available in public databases for the design of specific primers to be employed in the PCR. However, until now the specificity and sensitivity of these primer sets have not been evaluated in parallel in order to propose the best PCR protocol to detect this pathogen in research laboratories.

Comparing the specificity of the 2 PCR protocols, the sequence of both primer pairs were species-specific for Tenacibaculum maritimum, and no amplification products were obtained from chromosomal DNA of other non-T. maritimum bacteria tested. These results agree with those reported by the designers of both sets of primers (Toyama et al. 1996, Bader \& Shotts 1998). However, when all bacteria listed in Table 1 were screened, the number of strains identified by each primer pair was different. Whereas all the isolates rendered the specific amplicon when the MAR1-MAR2 (Toyama et al. 1996) primer pair was used, the Mar1Mar2 (Bader \& Shotts 1998) primer set failed to identify 3 isolates. However, the digestion patterns of the MAR1-MAR2 amplified products of $1088 \mathrm{bp}$ with the restriction enzymes PVuI and SacII allowed us to confirm the assignation of all the strains to the T. maritimum species.

Recently, Cepeda et al. (2003) also employed the Mar1-Mar2 primer pair, making modifications to the PCR programme described by Bader \& Shotts (1998) in order to reduce the time to achieve the diagnosis of Tenacibaculum maritimum. However, when we used this protocol with pure cultures of T. maritimum strains using the same extraction system and identical conditions as described by these authors, none of isolates tested generated an amplification signal (data not shown). This failure should probably be attributed to the extremely short time (2 s) employed in the annealing step, although we can not rule out the influence of other variables which theoretically could alter the test performance, such as source of reagents or disposable supplies.

In the present study, the sensitivity of both PCR detection methods was also different. It has been reported that sensitivity of PCR varies depending on the size of amplicons, and generally primers yielding smaller amplicons will be able to detect lower levels of target organisms (Otta et al. 1999, Hossain et al. 2001). However, our results using either pure or mixed cultures showed a reduction of sensitivity in at least one order of magnitude of the Mar1-Mar2 primer pair in comparison with MAR1-MAR2, although the former primer set yield a shorter amplicon (approximately $700 \mathrm{bp}$ ) than the latter one. 
Our study has shown that when the single PCR protocol of Toyama et al. (1996) was used with DNA extracted from seeded mucus, skin tissue and blood samples the sensitivity level was 10- to 100-fold lower than that observed with pure and mixed cultures, probably due to presence of host DNA and undefined inhibitors of PCR (Wilson 1997). This level of sensitivity is probably sufficient to detect Tenacibaculum maritimum acute infections in fish, but not when the pathogen is present in very low numbers in asymptomatic or carrier fish.

A nested PCR approach greatly increases the sensitivity of detection, and can be useful for the detection of very low copy numbers of template (Osorio \& Toranzo 2002). In our case the nested PCR assay supports this fact since an increase in sensitivity of at least 100 times was observed compared to conventional $\mathrm{PCR}_{i}$ this sensitivity is in the same range as those achieved for other bacterial fish pathogens (Osorio et al. 1999, Taylor \& Winton 2002). Although, we found that all tissues sampled could be used to detect the bacterium in a nested PCR protocol, negative results were obtained when using DNA extracted from kidney samples in a single PCR. Similar problems in detecting other fish pathogens in kidney have been attributed to PCR inhibitors (Chase \& Pascho 1998). The tissues that allowed detection of Tenacibaculum maritimum most easily were the skin and mucus with detection limits of about to $10^{2} \mathrm{CFU} \mathrm{g}^{-1}$ to $10^{3} \mathrm{CFU} \mathrm{ml}^{-1}$ respectively. This finding is in agreement with the observation previously reported for F. columnare by Bader et al. (2003). Therefore, the use of nested PCR with the MAR1MAR2 primer set in mucus samples becomes a useful, rapid and non-destructive procedure for the detection of T. maritimum in carrier fish.

In summary, on the basis of the results obtained in this work we propose the Toyama et al. (1996) PCR procedure as the most adequate for an accurate detection of Tenacibaculum maritimum in diagnostic pathology as well as in epidemiological studies of gliding bacterial disease of marine fish. In addition, the nested PCR provides at least 100 times more sensitivity than conventional PCR for the detection of T. maritimum not only in pure and mixed bacterial cultures, but also in experimentally seeded fish tissues. The accuracy of this method is currently being investigated with natural samples from different fish farms in order to evaluate its efficacy, under field conditions, in detecting the pathogen in diseased and asymptomatic carrier fish.

Acknowledgements. This work was supported in part by Grants PETRI95-0657.01.OP, ACU01-012, and AGL200407037 from the Ministerio de Ciencia y Tecnología (Spain). R. A.-H. would like to thank Programs BID-CONICYT, Chile for the fellowship.

\section{LITERATURE CITED}

Austin B, Austin A (1999) Bacterial fish pathogen: disease of farmed and wild fish, 3rd edn (revised). Springer-Praxis series in aquaculture and fisheries. Springer-Verlag, London

Avendaño-Herrera R, Magariños B, López-Romalde S, Romalde JL, Toranzo AE (2004a) Phenotypic characterization and description of 2 major O-serotypes in Tenacibaculum maritimum strains isolated from marine fishes. Dis Aquat Org 58:1-8

Avendaño-Herrera R, Rodríguez J, Magariños B, Romalde JL, Toranzo AE (2004b) Intraspecific diversity of the marine fish pathogen Tenacibaculum maritimum as determined by randomly amplified polymorphic DNA-PCR. J Appl Microbiol 96:871-877

Bader JA, Shotts EB (1998) Identification of Flavobacterium and Flexibacter species by species-specific polymerase chain reaction primers to the 16S ribosomal RNA gene. J Aquat Anim Health 10:311-319

Bader JA, Starliper CE (2002) The genera Flavobacterium and Flexibacter. In: Cunninghan CO (ed) Molecular diagnosis of salmonid diseases. Kluwer Academic Publishers, Dordrecht, p 99-139

Bader JA, Shoemaker CA, Klesius PH (2003) Rapid detection of columnaris disease in channel catfish (Ictalurus punctatus) with a new species-specific 16-S rRNA gene based PCR primer for Flavobacterium columnare. J Microbiol Methods 52:209-220

Bernardet JF, Campbell AC, Buswell JA (1990) Flexibacter maritimus is the agent of 'black patch necrosis' in Dover sole in Scotland. Dis Aquat Org 8:233-237

Cepeda C, García-Márquez S, Santos I (2003) Detection of Flexibacter maritimus in fish tissue using nested PCR amplification. J Fish Dis 26:65-70

Chase DM, Pascho RJ (1998) Development of a nested polymerase chain reaction for amplification of a sequence of a sequence of the p57 gene of Renibacterium salmoninarum that provides a highly sensitive method for detection of the bacterium in salmonid kidney. Dis Aquat Org 34:223-229

Chen MF, Henry-Ford D, Groff JM (1995) Isolation and characterization of Flexibacter maritimus from marine fishes of California. J Aquat Anim Health 7:318-326

Cunningham CO (2002) Molecular diagnosis of fish and shellfish diseases: present status and potential use in disease control. Aquaculture 206:19-55

Devesa S, Barja JL, Toranzo AE (1989) Ulcerative skin and fin lesions in reared turbot, Scophthalmus maximus (L). J Fish Dis 12:323-333

Edwards U, Rogall T, Bloecker H, Emde M, Boettger EC (1989) Isolation and direct complete nucleotide determination of entire genes. Characterization of a gene coding for 16S ribosomal RNA. Nucleic Acids Res 28:1942-1946

Evans JJ, Shoemaker CA, Klesius PH (2001) Distribution of Streptococcus iniae in hybrid striped bass (Morone chrysops $x$ Morone saxatilis) following nare inoculation. Aquaculture 194:233-243

Hossain MSA, Otta SK, Karunasagar I, Karunasagar I (2001) Detection of white spot syndrome virus (WSSV) in wild captured shrimp and in non-cultured crustaceans from shrimp ponds in Bangladesh by polymerase chain reaction. Fish Pathol 36:93-95

McVicar AH, White PG (1979) Fin and skin necrosis of cultivated Dover sole, Solea solea (L). J Fish Dis 2:557-562

Osorio CR, Toranzo AE (2002) DNA-based diagnostic in sea farming. In: Fingerman, M, Nagabhushanam R (eds) Recent advances in marine biotechnology, Vol 7. Seafood 
safety and human health. Science Publishers, Enfield, NH, p 253-311

Osorio CR, Collins MD, Toranzo AE, Barja JL, Romalde JL (1999) 16S rRNA gene sequence analysis of Photobacterium damselae and nested PCR method for rapid detection of the causative agent of fish Pasteurellosis. Appl Environ Microbiol 65:2942-2946

Ostland VE, LaTrace C, Morrison D, Ferguson HW (1999) Flexibacter maritimus associated with a bacterial stomatitis in Atlantic salmon smolts reared in net-pens in British Columbia. J Aquat Anim Health 11:35-44

Otta SK, Shubha G, Joseph B, Chakraborty A, Kurunasagar I, Kurunasagar I (1999) Polymerase chain reaction (PCR) detection of white spot syndrome virus (WSSV) in cultured and wild crustacean in India. Dis Aquat Org 38:67-70

Pazos F, Santos Y, Núñez S, Toranzo AE (1993) Increasing occurrence of Flexibacter maritimus in the marine aquaculture of Spain. Am Fish Soc/Fish Health Sec Newsl 21: $1-2$

Pazos F, Santos Y, Macias AR, Nuñez S, Toranzo AE (1996) Evaluation of media for the successful culture of Flexibacter maritimus. J Fish Dis 19:193-197

Romalde JL, Magariños B, Villar C, Barja JL, Toranzo AE (1999) Genetic analysis of turbot pathogenic Streptococcus parauberis strains by ribotyping and random amplified polymorphic DNA. FEMS Microbiol Lett 459:297-304

Editorial responsibility: Carey Cunningham,

Aberdeen, UK
Santos Y, Pazos F, Barja JL (1999) Flexibacter maritimus causal agent of flexibacteriosis in marine fish. In: Oliver $\mathrm{G}$ (ed) ICES identification leaflets for diseases and parasites of fish and shellfish, No. 55. International Council for the Exploration of the Sea, Copenhagen, p 1-6

Suzuki M, Nakagawa Y, Harayama S, Yamamoto S (2001) Phylogenetic analysis and taxonomic study of marine Cytophaga-like bacteria: proposal for Tenacibaculum gen. nov. with Tenacibaculum maritimum comb. nov. and Tenacibaculum ovolyticum comb. nov., and description of Tenacibaculum mesophilum sp. nov. and Tenacibaculum amylolyticum sp. nov. Int J Syst Evol Microbiol 51: $1639-1652$

Taylor PW, Winton JR (2002) Optimization of nested Polymerase Chain Reaction assays for identification of Aeromonas salmonicida, Yersinia ruckeri, and Flavobacterium psychrophilum. J Aquat Anim Health 14:216-224

Toyama T, Kita-Tsukamoto K, Wakabayashi H (1996) Identification of Flexibacter maritimus, Flavobacterium branchiophilum and Cytophaga columnaris by PCR targeted 16S Ribosomal DNA. Fish Pathol 31:25-31

Wakabayashi H, Hikida M, Masumura K (1984) Flexibacter infection in cultured marine fish in Japan. Helgol Meeresunters 37:587-593

Wilson IG (1997) Inhibition and facilitation of nucleic acid amplification. Appl Environ Microbiol 63:3741-3751

Submitted: April 5, 2004; Accepted: June 28, 2004

Proofs received from author(s): October 29, 2004 